\title{
CINTA EKOLOGIS DALAM PENDEKATAN ESTETIKA TEOLOGIS KRISTIANI
}

Yosef Irianto Segu

Graduate Student

Faculty of Philosophy

Parahyangan Catholic University

Bandung, Indonesia

\section{Abstract:}

Human's mind and behaviour have been influenced by the understanding of who human beings are. Realising identity on the level of knowledge might have revealed human's exclusive, dominant, and alienating nature. Nature is seen as an object of a pragmatic approach for the sake of human's development. Nature is not so much seen as something meaningful as a necessity to fulfill the needs of the human being. The field of knowledge and discourse is always limited in itself and human's relationship with the nature cannot merely accommodated by ideas and concepts. Human's relationship with nature needs to be built with love. Love is the self's involvement as a whole to participate in the life of the other, that is, through the real and constructive encounters of human and nature that preserve the beautiful existence of both. One of the fusions between human and nature is in the area of aesthetics, and in this article, of theological aesthetics. While knowledge and concept could not be imposed on the relation between human and nature, humans might need a different approach in the area of experience. Human experience in relation to nature is not always linear, but continuously invites humans to explore the aesthetic and theological territories, in order to offer meanings so that they can go beyond their identity or exclusivity in knowledge and concept. This balance may improve human's relationships with the nature.

\section{Keywords:}

theological aesthetics - aesthetic theology - problem of anthropocentrism knowledge - ecological love $\bullet$ aesthetic experience $\bullet$ spiritual experience 


\section{Pendahuluan}

Maaf tidak ada gambaryang indah untuk perubahan iklim. ${ }^{1}$ Kalimat tersebut mengutarakan kekhawatiran dan harapan. Kekhawatiran dan harapan tersebut sudah di mulai pada September 1988 di bumi Britania. Dalam bukunya yang bertajuk The Carbon War, seorang pengajar di Royal School of Mines, Jeremy Leggett, mengatakan bahwa 1988 merupakan tahun istimewa yang tidak pernah terjadi dalam sejarah. Pada tahun ini manusia mulai menghadapi masalah besar dengan alam berkaitan dengan penggunaan karbon di sejumlah negara yang memicu kerusakan alam. Perdana Menteri Inggris, Margaret Thatcher, mengingatkan rakyatnya bahwa, "Kita tanpa sadar telah memulai eksperimen yang masif terhadap sistem planet". Pada awal 1990, isu pemanasan global pun menggema di berbagai belahan dunia. Di tengah tekanan publik pada Desember 1990, Majelis Umum PBB sepakat membuat perjanjian untuk menangani perubahan iklim. Beberapa konferensi internasional diselenggarakan, sampai yang terbaru diadakan pada 30 November hingga 11 Desember 2015 di Paris, Perancis. ${ }^{2}$ Konferensi Tingkat Tinggi Perubahan Iklim digagas oleh Perserikatan Bangsa-Bangsa (UNFCCC COP21). Manusia butuh berpuluh tahun untuk menyadari bahwa bumi sebagai rumah manusia terancam.

Kesepakatan bersama yang terjadi di Paris akan menempuh jalan yang panjang. Kegagalan kesepakatan bersama dengan komitmen bersama sebelum konferensi di Paris, menunjukan bahwa ada mentalitas berbahaya yang menunggangi teknologi untuk melakukan eksperimen yang masif terhadap alam. Mentalitas ini lahir dari 'antroposentrisme' yang berlebihan, yang kadang-kadang berbusana etnosentrisme dan chauvinisme. Tulisan ini hendak mempertemukan keprihatinan ekologis dan kecintaan (passion) kristiani yang berpusat pada keindahan abadi dalam diri Allah melalui wajah Kristus. Cinta ekologis yang estetis diusulkan sebagai pendekatan teosentris untuk mengimbangi mentalitas antroposentris yang telah memunculkan dominasi manusia atas alam.

\section{Status Quaestionis}

'Antroposentrisme' lahir dari penekanan antroposentris yang terlalu besar, yaitu manusia sebagai pusat alam semesta. Mentalitas ini menunggangi teknologi yang serentak menjadi motor penggerak lahirnya penggunaan teknologi tersebut secara destruktif. Mentalitas ini menjelma secara halus 
dengan menunggangi pertumbuhan dan perkembangan dunia. Alam rusak karena manusia memosisikan diri sebagai tuan yang berhak mengambil kekayaan alam, dan setelah itu tidak ada keinginan untuk memperbaiki kembali alam yang rusak itu. Mentalitas ini memunculkan tegangan antara relasi manusia dengan alam yang berdampak pada seluruh aspek kehidupan manusia. Alam yang rusak mempengaruhi bidang ekonomi, sosial, politik, budaya, dan keamanan manusia.

Perjalanan manusia sebagai 'pusat; tidak bisa dilepaskan dari sejarah perkembangan akal di Barat. Setelah Barat melewati masa Abad Pertengahan, muncul Zaman Renaisans. Dari zaman itu hingga memasuki Zaman Modern, pengagungan terhadap akal begitu besar. Cara berpikir tradisional (Abad Pertengahan) didobrak dengan menekankan metode berpikir secara rasional. ${ }^{3}$ Merebaknya ilmu pengetahuan yang bertolak dari rasio, merupakan sebuah terobosan besar di dunia. Ilmu pengetahuan semakin berkembang dan mampu menjawab masalah-masalah manusia yang semakin partikular dan kompleks. Ilmu pengetahuan memberikan perubahan kepada dunia menjadi canggih dan modern. Perkembangan akal juga diarahkan agar manusia mendapatkan kejelasan mengenai identitas dirinya. Konsekuensi ialah bahwa identitas diri yang terus menerus mengedepankan antroposentrisme itu mengaburkan fokus manusia terhadap sisi teosentris kenyataan. ${ }^{4}$

Dengan akal, manusia berupaya menjadi pribadi mandiri yang eksklusif. Pribadi mandiri merupakan pribadi yang tidak ditentukan dan tidak bergantung (lagi) pada yang yang Ilahi. Cara hidup secara rasional lebih diminati ketimbang cara hidup yang merefleksikan Allah lewat rasa dan indera. Manusia dapat dikatakan 'memberontak' terhadap yang Ilahi karena rasionalitasnya. Manusia berusaha melibas segala ketergantungan pada yang Ilahi, dan tidak ingin diatur lagi oleh yang Ilahi. Manusia adalah tuan atas dirinya sendiri, dan karenanya juga terhadap dunia tempat hidupnya.

Paradigma manusia adalah tuan telah memberikan efek perubahan terhadap relasi manusia dengan alam. Manusia mengubah alur relasi dengan alam. Semula manusia terkungkung oleh alam dan manusia bergantung sepenuhnya pada kekuatan alam. Situasi tersebut ditandai dengan zaman dinamisme. Manusia di zaman tersebut masih berpikir alam sebagai kekuatan yang tertinggi karena alam dianggap mendatangkan 
kebahagiaan dan juga penderitaan. Manusia menyembah pohon, batu, laut, api dan benda-benda alam yang dianggap memberikan kekuatan. Bahkan, alam diposisikan sebagai yang tertinggi yang dapat mengendalikan hidup manusia. Singkat kata, alam dipahami sebagai tuhan yang bisa memberikan kebahagiaan dan hukuman. ${ }^{5}$ Jika dalam hal ini manusia prasejarah berupaya beradaptasi dengan alam, maka lain halnya dengan manusia modern yang berupaya memodifikasi alam.

Perkembangan akal terjadi seiring dengan menguatnya antroposentrisme. Segala perkembangan ilmu pengetahuan cenderung berkiblat pada kepentingan manusia semata. Perkembangan rasio dan antroposentrisme memberi kemajuan sekaligus masalah baru, contohnya, teknologi. Perkembangan teknologi yang bertujuan untuk memanusiakan manusia bisa jadi telah bergeser dari maksudnya. Perkembangan teknologi hanya dinikmati oleh segelintir orang dan bahkan ia menjadi alat bagi manusia untuk memepertegas antroposentrisme yang agresif. Tujuan bagi kepentingan diri sendiri dikejar dengan cara menundukkan faktor di luar dirinya baik manusia lain maupun alam. ${ }^{6}$ Ternyata kegilaan manusia terhadap antroposentrisme yang agresif itu telah menggoncangkan keseimbangan yang baik antara relasi manusia dan alam. Yang kuat adalah yang menang. Ini menjadi model yang dipakai manusia untuk menegaskan aku (diri manusia) sebagai pusat. Masalah ekologis yang disebabkan antroposentrisme agresif akhirnya memunculkan sikap eksklusif mengsubordinatkan, dan dominatif terhadap alam.

Sikap eksklusif ditandai keyakinan bahwa manusia adalah satusatunya pusat alam semesta. Manusia menjadi pusat alam semesta, juga karena pandangan Kartusianisme. Model berefleksi cogito ergo sum (Descartes) memberi implikasi bahwa alam dianggap eksis sejauh manusia memikirkannya. Gaya berpikir kartusian ini memberikan potensi idealisme dan mekanisme. ${ }^{7}$ Idealisme juga ditandai bahwa manusia adalah pusat yang ideal. Manusia adalah makhluk sempurna. Bedasarkan evolusi, manusia memilik otak yang lebih baik daripada organisme sebelumnya. Karen Armstrong memberikan analisisnya bahwa manusia modern mempunyai otak baru yang disebut dalam istilah ilmiah neokorteks. "Otak baru" ini merupakan hasil dari evolusi dari "otak tua". Otak tua didominasi oleh mekanisme saraf untuk makan (feeding), berkelahi (fighting), melarikan diri (fleing), dan kawin (reproduction). ${ }^{8}$ Dalam otak baru, terdapat pusat kekuatan 
penalaran yang memungkinkan manusia untuk memikirkan dunia dan dirinya sendiri. Arah perkembangan rasio ini diarahkan dan bertumpu pada manusia sebagai aku. Manusia sebagai aktor panggung dunia telah mempersempit dimensi kehidupan karena hanya memfokuskan segala sesuatu pada dirinya secara normatif. Sementara itu, cara berpikir mekanis tampil dalam upaya manusia melihat lingkungan sejauh manusia pikirkan. Kehidupan alam terdiri atas benda-benda yang dianggap tidak bernafas dan makhluk yang hidup seperti tumbuhan dan hewan, ditempatkan dari sisi asas manfaat dan keuntungan. Alam tidak ubahnya seperti robot yang digunakan terus menerus untuk kepentingan manusia. Setelah mengalami kerusakan, mentalitas "membuang yang tidak berguna" menjadi kecenderungan manusia yang utama. Alam tidak dilihat pada dirinya sendiri. Tidak ada relasi manusia dengan organisme yang ada di alam semesta, kecuali paradigma bahwa alam dilihat semata-mata dari keuntungannya bagi manusia.

Manusia mengsubordinatkan makhluk lain. Kata subordinat mempunyai maksud meninggikan diri dan memisahkan diri dari yang lain. Pertama, manusia digolongkan dalam kasta paling tinggi dibandingkan hewan dan tumbuhan serta alam. Teori evolusi Darwin telah memberi implikasi subordinasi semacam ini. ${ }^{9}$ Pada awalnya manusia diseleksi oleh alam selama proses evolusi. Puncak evolusi manusia adalah homo sapiens. Homo Sapiens dianggap sebagai perbaikan dari evolusi tingkat paling rendah. Yang diukur dalam evolusi ialah ciri-ciri fisik. Bentuk-betuk fisik yang tidak sesuai dengan evolusi terbaik seolah-olah dianggap sebagai kelas rendah. Evolusi berjalan linier dan dari bawah ke atas. Bentuk fisik yang baik sebagai wilayah atas dan wilayah atas hanya memandang sebelah mata kepada wilayah di bawahnya. Akhirnya, manusia merendahkan makhluk lain karena tidak sempurnanya fisik mahluk hidup lain; perendahan juga terjadi di antara manusia sendiri.

Kedua, manusia memisahkan diri dari mahkluk lainnya. Penafsiran yang keliru terhadap pernyataan Kitab Suci kristiani yang menyatakan bahwa manusia adalah citra Allah, semakin mempertegas pemisahan itu. Emil Brunner, salah satu teolog yang memperhatikan ekologi, berpendapat bahwa perspektif kristiani telah menyodorkan paradigma bahwa Allah dan dunia adalah subjek dan objek yang terpisah. Keterpisahan antara 
Allah dan dunia ciptaan-Nya membawa konsekuensi, yaitu manusia cenderung mendekati Allah, tapi mengabaikan peran lingkungan hidup. Upaya mencintai Allah tidak berjalan lurus dengan upaya mencintai alam semesta. Sifat keilahian yang dimiliki manusia seolah-olah menjadi modal utama bagi manusia untuk memosisikan dirinya lebih tinggi dari alam. Hal tersebut diperburuk dengan penafsiran firman Allah kepada manusia untuk menaklukkan bumi (Kejadian 1:28) serta untuk mengusahakan dan memeliharanya (Kejadian 2:15). ${ }^{10}$

Sikap dominatif manusia terhadap alam ditunjukkan dengan sikap yang menguasai alam. The Historical Roots of Our Ecological Crisis, karya Lynn White, memperlihatkan asal mula sikap dominatif manusia terhadap alam. White berpendapat bahwa Allah yang dijelaskan di dalam Kitab Suci Perjanjian Lama adalah Allah yang terpisah dari ciptaan-Nya, maka alam dipahami sebagai yang terpisah pula dari Allah. ${ }^{11}$ Pemikiran tersebut diadopsi manusia sebagai "citra Allah" untuk menegaskan dirinya yang terpisah dari alam. Keterpisahan antara manusia dengan alam mencetuskan paradigma dualisme. Efek yang ditimbulkan ialah sikap kesewenangwenangan manusia dalam mengeksploitasi alam yang terpisah dari Allah.

Dengan berkembangnya akal manusia dan perhatian terhadap antroposentrisme yang tinggi, manusia berusaha untuk melawan dominasi alam. Manusia dapat berpikir secara baik sehingga mampu belajar bertahan dan mengatasi alam. Namun, relasi manusia dengan alam ditandai dengan sikap manusia memosisikan diri sebagai subjek dan alam hanya objek. Manusia mempunyai kemampuan untuk mengeksploitasi alam secara pragmatis demi kebutuhan manusia. Ketika manusia menempatkan diri sebagai pusat, ia akhirnya memberikan prioritas tertinggi pada kepentingannya sendiri. ${ }^{12}$

Secara garis besar, akar masalah ekologis disebabkan manusia melupakan dimensi teosentris ketika berelasi dengan alam dan penekanan antroposentris yang terlalu agresif. Manusia sebagai pusat merupakan hasil antroposentrisme, sehingga menganggap dirinya terpisah dari alam. Dengan bersifat eksklusif, mengsubordinat, dan dominatif, manusia bergerak dari distingsi menuju ke distansi dan kemudian dualisme. Pembedaan antara manusia dan yang bukan manusia menjadi jarak antara manusia dan yang bukan manusia. Gerak ini selanjutnya menuju pemisahan antara manusia dengan yang nonmanusia. Pemisahan yang bersifat subjek- 
objek dan disokong oleh keserakahan ini telah menghasilkan eksploitasi.

Diperlukan sikap kritis berkaitan dengan antroposentris agresif. Masalah ekologis bukan lagi perkara manusia dengan alam, tapi relasi dengan yang Ilahi, dan sesama manusia pun ikut terseret dalam permasalahan ini. Keterpusatan alam semesta pada diri manusia telah merusak hubungan manusia dengan alam dan Allah. Perkembangan akal, karenanya, harus diarahkan lagi pada usaha memanusiakan manusia yang sesuai dengan kemuliaan Allah. Perkembangan akal seharusnya tidak mencoret kesatuan relasi dengan alam, sesama manusia, dan Allah. Alam merupakan salah satu bagian dari penciptaan Allah. Sallie McFague pernah memberikan metafor organik bahwa alam semesta adalah tubuh Allah. Allah, melalui Roh Kudus, menghidupi dunia ini. ${ }^{13}$ Metafor ini dapat mendorong manusia untuk tidak melihat dirinya terlepas dari alam semesta, agar manusia tidak berdiri sebagai tuan dan alam seakan-akan dipandang sebagai pembantu.

Perkembanganakalyangmencoretnilai-nilaiteosentris membuntungkan intuisi manusia terhadap masalah ekologi. Perkembangan akal adalah baik karena manusia memasuki tahap rasional yang lebih tinggi. Problemnya adalah bahwa jawaban yang disodorkan oleh akal seringkali tidak menjadi solusi bagi masalah ekologi. Ekologi mempunyai dimensi pada dirinya sendiri yang tidak selalu dapat ditangkap melalui akal, seperti halnya, nilai instrinsik alam yaitu keindahan, moralitas manusia yang mempengaruhi eksploitasi alam secara terstrukur, dan masalah relasi manusia dengan Allah.

\section{Estetika Teologis}

Pada bagian pertama triologi Hans Urs von Balthasar, The Glory of the Lord: A Theological Aesthetics, ada upaya untuk mengemukakan teologi estetis sekaligus estetika teologis. ${ }^{14}$ Estetika teologis dikehendaki oleh Balthasar. Teologis estetis dapat dipahami sebagai aktifitas berteologi yang menggunakan estetika sebagai kunci masuk ke dalam pintu pembahasan teologis. Bila teologi didefiniskan sebagai scientia fidei, estetika merupakan metode pendekatannya. Estetika juga bermakna sebagai sistem pengetahuan melalui penginderaan atau pengalaman. Estetika teologis mencoba menyingkapkan Allah melalui keindahan. Keindahan pada dirinya sendiri bersifat transenden karena memuat sifat ilahi. Sifat ilahi terpancarkan dalam atribut-atribut yaitu Ens unum, bonum, verum, pulchrum. 
Estetika tidak mengurusi keindahan secara dekoratif atau kosmetis pada permukaan, melainkan lebih perkara kebenaran dan kebaikan. Kebenaran dan kebaikan yang terjadi pada diri sendirinya adalah indah. ${ }^{15}$ Keindahan dialami karena terdapat perilaku yang mengandung unsurunsur kebenaran dan kebaikan. Kebaikan (bonum) merupakan bahasan etika, kebenaran (verum) dibahas dalam logika dan epistemologi, dan keindahan (pulchrum) menjadi wilayah estetika. Mortimer J. Adler, penulis Six Great Ideas, menegaskan bahwa terdapat dua ide besar yang menjadi poros kehidupan manusia. Pertama ialah kebebasan, kesetaraan, dan keadilan (liberty, equality, dan justice). Kedua ialah kebenaran, kebaikan, dan keindahan (verum, bonum, dan Pulchrum). Dua ide ini merupakan perubahan yang penting untuk dilakukan (mutatis mutandis). Ide tentang kebebasan, kesetaran, dan keadilan merupakan ide yang menekankan soal apa yang kita lakukan (ideas we act on), sedangkan ide tentang kebenaran, kebaikan, dan keindahan merupakan ide untuk membuat penilaian (ideas we judge by). Dari dua ide besar tersebut, Balthasar menaruh perhatian besar terhadap ide besar yang kedua yaitu kebenaran, kebaikan, dan keindahan. Bagi Balthasar, keindahan berjalan seiring dengan yang benar dan baik. Keterkaitan ini tidak mungkin dilepas satu sama lain. Keindahan mengundang imajinasi untuk merangkul akal dan emosi pada kesadaran estetis. Kesadaran estetis merupakan kepekaan bahwa keindahan menjadi sahabat sejati kebenaran dan kebaikan. Jika ada sesuatu yang tidak terlihat 'indah' dari alam ialah karena tindakan manusia yang tidak adil terhadap alam, maka timbul kesadaran bahwa ada yang tidak benar dan tidak baik dari perilaku manusia terhadap alam. Alam tidak diberi kebebasan (berada dan berkembang pada dirinya sendiri) karena eksistensinya hanya diukur sejauh manusia memikirkan manfaatnya. Kesetaraan alam pun dilupakan melalui sikap antroposentrisme subordinatif. Pertanyaannya: bagaimana estetika teologis menawarkan pandangan untuk mengatasi alam yang rusak?

Dengan mengacu pada pertobatan ekologis yang dimaklumkan Paus Fransiskus, kalimat pertobatan ekologis dapat diteropong dengan kacamata estetika teologis. Pertobatan ekologis merupakan tindakan keindahan, karena manusia berusaha melepaskan atribut-atribut keburukan pada dirinya sendiri, sehingga dengan bersih ia pantas bersatu dengan Allah. 
Pertobatan ekologis bukan perkara alam semata-mata, tetapi keterlibatan manusia secara utuh. ${ }^{16}$ Pertobatan ekologis tidak luput dari perubahan moral manusia, yakni perubahan dalam memandang alam dan upaya untuk masuk dalam situasi estetika demi mendekati Allah. Oleh karena itu, keindahan yang ditawarkan estetika teologis menyangkut kebenaran moralitas manusia dan kebaikan beretika terhadap alam. Keindahan ini merangkul nilai-nilai kebebasan, kesetaraan, dan keadilan. Antroposentrisme agresif telah mengaburkan nilai-nilai kebebasan, kesetaraan, dan keadilan yang menjadi hak alam dan manusia. Pengaburan ini juga merupakan perusakan manusia terhadap karya ciptaan Allah.

Berkaitan dengan kebenaran, soal yang diajukan adalah bagaimana secara moral manusia bertindak arif terhadap alam (benar-antropologis). Kebenaran ini bertolak pada verifikasi perbuatan manusia terhadap alam, yang mempengaruhi relasi terhadap sesama manusia. Pada tahap pertama, pertobatan ini berkaitan penjelasan benar atau salah tindakan manusia terhadap alam. Pertobatan ekologis membutuhkan ilmu pengetahuan untuk menjelaskan dampak kerusakan alam secara real dan langsung. Tahap kedua: sejauh mana dampak itu menimbulkan rusaknya relasi dengan sesama manusia. Sesama manusia meliputi manusia saat ini dan generasi selanjutnya. Alam yang rusak merupakan bentuk ketidakpedulian dan ketidakadilan manusia saat ini kepada sesamanya di zaman yang sama maupun generasi manusia selanjutnya. Dalam ensiklik Laudato Si (2015), Paus Fransiskus memberikan peringatan atas keserakahan terhadap alam yang menyebabkan ketidakadilan, kemiskinan, dan penderitaan pada masyarakat miskin dan generasi manusia selanjutnya. Jika manusia hanya berkutat pada kesenangan sendiri dan keselamatan secara invidualistis, rekam jejak kekerasan akan terjadi secara masif dan terstruktur. Hal itu ditandai lewat upaya manusia yang terdesak, untuk belomba-lomba mengambil keuntungan dari alam.

John Stott menegaskan bahwa manusia berdosa karena menghadapi alam melebihi pemenuhan kebutuhannya, dan karena serentak manusia meninggikan keserakahannya. Ada pergeseran makna dari needy menjadi greedy. ${ }^{17}$ Kegagalan dalam melaksanakan tugas kepemimpinan atas alam merupakan kegagalan manusia juga dalam mengendalikan dirinya, khususnya keinginan-keinginannya. Kegagalan ini ikut mereduksi label imago 
Dei. Manusia tidak mampu merefleksikan citra Allah yang mengundang komitmen untuk memberikan cinta kepada sesama manusia dan alam. Antropologisme yang sesat tecermin dalam keserakahan dan moralitas egoistis. Oleh karena itu, Paus Fransiskus mendorong gerakan moral yang menenggelamkan sisi self-centeredness dan menuju reality-centeredness.

Dari sisi kebaikan, perlu dibicarakan etika terhadap alam (baikbiosfer). Usaha manusia untuk mendekati alam, mau tidak mau harus memiliki standar yang memahami keadaan alam itu sendiri. Dampak kerusakan alam yang real harus menantang manusia untuk merefleksikan sikap antroposentrisnya. Jürgen Moltmann pernah memberikan kritik terhadap pemahaman antroposentrisme. Ia mengutip hipotesis "Gaia", bahwa sistem bumi adalah sistem bio-kibernetik universal dengan tren ke arah keseimbangan. Planet bumi mesti dilihat sebagai sistem interaksi dan timbal balik yang berjuan untuk menciptakan kondisi lingkungan yang paling memungkinkan untuk hidup. ${ }^{18}$ Oleh sebab itu, J. E. Lovelock, penulis Gaia: A New Look at Life on Earth, mengusulkan perubahan paradigma berpikir biosentris. Bagi Moltmann, paradigma ini berusaha menantang manusia untuk mengakhiri pemahaman diri dan tingkah laku yang antroposentris. Ia mengajukan refleksi teologis berdasarkan perjanjian dalam Kitab Kejadian 9:9-10. Perjanjian tersebut bukan hanya terjadi antara Allah dan manusia, sehingga manusia seakan-akan menjadi pusat segalanya dan wakil Allah di dunia. Perjanjian tersebut berlangsung antara Allah dan manusia serta keturunannya, dan dengan semua makhluk hidup. Maka, manusia tidak bisa mengklaim kedudukan yang lebih tinggi dibanding alam karena semuanya mempunyai posisi sebagai rekan Allah.

Dalam perspektif biosfer, alam mempunyai hak hidup pada dirinya sendiri. Alam memiliki unsur pada dirinya sendiri yang membawa nilai di dalamnya. Batu memiliki nilai pada dirinya sendiri yang tidak tergantung pada perspektif manusia. Batu hadir di dunia bedasarkan hak kebatuanya. Batu ada bukan demi kepentingan manusia. Dalam batu terdapat sisi-sisi yang dapat diukur dan unsur-unsur alam yang menyusunnya. Demikianlah seluruh makhluk hidup memiliki nilai inheren yang terlepas dari kepentingannya bagi manusia. Lingkungan mempunyai tujuannya masingmasing, maka tiap makhluk nonbuman mempunyai hak mendapatkan perlakuan sesuai dengan tujuan yang melekat padanya.

Evolusi tidak selalu bersifat linier. Pengertian tersebut menegaskan bahwa alam mempunyai kehidupan sendiri dengan segala nilai-nilai yang 
terkandung di dalamnya. Henry Bergson menjelaskan bahwa proses evolusi adalah usaha elan vital untuk membebaskan diri dari determinisme materi. ${ }^{19}$ Wilayah vegetatif, instingtif, dan rasional selalu bersifat dinamis dan tidak dianggap sebagai tahap-tahap hierarkis dalam evolusi, melainkan sebagai tiga arah, tiga kemungkinan yang dipilih untuk membebaskan diri dari keterikatan pada materi. Rasio yang dianggap lebih tinggi daripada yang vegetatif dan instingtif, ternyata arahnya tidak linier karena yang vegetatif dan instingtif punya wilayah yang kompleks, rumit, dan luas.

Ada kemungkinan-kemungkinan baik yang dihasilkan oleh tumbuhan dan binatang sehingga manusia tidak bisa mengatakan bahwa tumbuhan dan binatang itu tidak lebih baik dari manusia. Dalam Kitab Kejadian, segala makhluk itu baik dalam harmoni sehingga tidak ada indikasi untuk menunjukan mana yang lebih baik atau yang tidak lebih baik. Semua mahkluk adalah baik karena diberkati Allah untuk saling bekerja sama. Allah melihara makhluk dengan bijaksana sehingga setiap makhluk mempunyai perkembangan di dalam dirinya sendiri. ${ }^{20}$ Alam raya merupakan organisme yang bidup. 'Hidup' dalam konteks ini tidak sekadar tumbuh, melainkan memuat pergerakan. Pergerakan ini ditimbulkan oleh gelombang dan massa, dan juga pergerakan molekul-molekul yang mempengaruhi benda tersebut dan benda lain. Ilmu pengetahuan berperan memahami ke mana gerak arah makhluk nonhuman ini.

Secara estetis, usaha manusia mendekati alam bertolak pada sisi teosentris yang bertujuan untuk memuliakan Tuhan. Dengan pendekatan estetis, manusia mendekati Allah. Sisi estetis-teosentris merangkul gerak benarantropologis dan baik-biosfer. Meminjam pemikiran ekologis Robert Elliot, alam semesta adalah kesatuan ekosistem yang terkait, maka kesadaran secara estetis ini juga didasarkan pada keterkaitan. Perbedaan antara ekosentrisme dan estetis-teosentrisme ialah bahwa pendekatan estetisteosentris mempunyai fokus yang tidak berhenti pada alam semesta sebagai ekosistem, seperti yang ditegaskan oleh Elliot tentang ekosentrisme. Pendekatan estetis-teosentris mencoba melampaui pemahaman ekosentris, karena bertolak pada yang transenden. Pendekatan estetis-teosentris melihat Allah itu indah karena serentak menghadirkan baik-biosfer dan benarantropologis.

Kembali pada pemikiran McFague yang menyakini bahwa alam semesta adalah tubuh Allah, muncul refleksi bahwa pergerakan alam semesta berada dalam diri Allah. Allah melakukan proses evolusi lewat Roh Kudus. 
Evolusi ini bersifat kreatif dan proses evolusi bersifat terbuka. Roh Kudus menggerakan yang nonbuman. Contohnya, dunia fisika. "Partikel Tuhan" yang diperkenalkan oleh Peter Higgs menjadi pencapaian terbaru. Ciri khas partikel ini adalah memberikan massa kepada materi. Dalam pembentukan alam semesta (proses kosmologi), gaya gravitasi merupakan gaya yang berperan paling penting dalam skala kosmik. Istilah "partikel Tuhan" hanyalah istilah ilmiah dan tidak merepresentasikan teologi tentang Tuhan. Namun, hal ini memunculkan refleksi tersendiri berupa ajakan kepada manusia untuk terus menerus memahami alam semesta sebagai bagian dari Tuhan. ${ }^{21}$ Pertanyaannya: siapakah yang akan mengadakan "partikel Tuhan"?

Seperti yang dijelaskan Thomas Aquinas melalui quinque viae, dikemukakan lima jalan sebagai bukti bahwa Allah ada. Pemikiran tentang quinque viae dipengaruhi oleh refleksi para filsuf Barat, contohnya, Plato, Aristoteles, dan Augustinus. A posteriori dipakai sebagai titik awal Thomas menjelaskan bahwa Allah ada. ${ }^{22}$ Bagi Thomas, eksistensi Allah mengacu ke pendapat-pendapatnya yang didasarkan pada pengalaman real dalam realitas. Eksistensi Allah dapat dibuktikan dengan gejala-gejala realitas yang diamati Thomas. Berikut adalah bukti-bukti bahwa Allah ada menurut Thomas Aquinas yaitu: gerak, adanya penyebab, adanya sesuatu yang dapat ada atau tidak ada, yang ada dari dunia ini mempunyai kesempurnaan tertentu, baik itu lebih maupun kurang, serta adanya keteraturan dan keterarahan alam. ${ }^{23}$ Ada tiga kategori yang dapat mengelompokkan lima jalan pembuktian eksistensi Allah. Tiga kategori ini saling berkaitan dan mengacu pada pembuktian secara kosmologis menyangkut pembuktian pertama, kedua dan ketiga yaitu tentang gerak, adanya penyebab, dan adanya sesuatu yang dapat ada atau tidak ada. Kategori kedua berkaitan dengan pembuktian secara ontologis, karena mulai dari refleksi tentang yang ada itu mempunyai kesempurnaan. Kategori kelima berkaitan dengan pembuktian bersifat teleologis, sebab pembuktian ini menjelaskan tentang keteraturan dalam alam dan tujuan keteraturan, yaitu Allah.

"Partikel Tuhan" merupakan salah satu hasil kreativitas Roh Allah dalam segala ciptaan-Nya yang tersingkap dalam ranah ilmu pengetahuan. Roh Allah sudah bekerja di awal penciptaan, dalam sejarah manusia sebelum dan sesudah kebangkitan Yesus Kristus. Manusia akan mengalam perjumpaan dengan alam yang penuh makna jika manusia mendekati Roh 
Kudus secara dinamis dan terus menerus. Roh Kudus mesti didekati dengan usaha manusia secara aktif, yakni dengan mengolah hati dan menyakini bahwa alam adalah ciptaan Allah yang memberikan keindahan. Keindahan memesona manusia dan mengundang manusia untuk masuk di dalamnya. Daya tarik Roh Kudus menggerakkan manusia untuk menyadari bahwa proses evolusi mengarah kepada yang sempurna, yaitu Kristus, Logos sejati, sebab Kristus merupakan puncak kebenaran, kebaikan, dan keindahan di dunia. Kreativitas Roh Kudus akhirnya menuju tujuan akhirnya (eschaton), yaitu kebersatuan dengan Allah.

Allah bukan alam. Alam merupakan salah satu bagian dari penciptaan. Alam memperlihatkan percikan-percikan keindahan Allah. Bagi Balthasar yang terpengaruh cara berpikir Aristotelian, diyakini bahwa yang tampak (Gestalt) dalam percikan hanyalah kilasan dari sebuah inti (ousia). Yang inti memang selalu sempurna, layaknya Plato mengagungkan dunia ide, namun ide membutuhkan bentuk untuk menyingkapkan dirinya. ${ }^{24} \mathrm{Jika}$ manusia memandang percikan keindahan alam semesta melalui penginderaan dan ilmu pengetahuan, bentuk percikan keindahan itu akan menyingkapkan Allah.

Muhammad Iqbal, seorang filsuf Islam dari Pakistan yang belajar di Universitas Cambridge dan München, menegaskan ultimate reality sebagai keindahan abadi. ${ }^{25}$ Keindahan abadi ini memercikkan keindahan pada karya-Nya. Memandang keindahan yang ilahi memberikan efek berupa cinta. Cinta lahir karena manusia tesergap keindahan abadi yang terpancar dalam keindahan alam. Manusia ditarik pada kekaguman keindahan ilahi. Akhirnya, dasar untuk memiliki sense of beauty ialah kekaguman, sebab alam merupakan karya seni Allah yang memuat keindahan sekaligus menuntut kebaikan dan kebenaran.

Pada umumnya keindahan merupakan bahasa alam ketika berbicara. Keindahan merupakan situasi awal bagaimana alam berbicara. Alam yang rusak merupakan bahasa kedua yang disebabkan ketidakpekaan manusia terhadap keindahan alam. Dengan kesadaran akan keindahan, manusia dapat mendengarkan bahasa alam. ${ }^{26}$ Bahasa alam memerlukan pengetahuan sebagai titik tolak kemudian masuk ke dalam pengalaman. Bahasa alam bukanlah sekadar bahasa isyarat. Ketidakmampuan menangkap bahasa alam adalah kelemahan batin manusia. Dari sudut pandang Otto Scharmer, kelemahan itu disebut blind spot. ${ }^{27}$ Bahasa alam menyentuh sisi kebatinan 
individual atau kelompok. Walaupun sisi kebatinan adalah misteri bagi manusia, namun sisi inilah yang menyimpan kepekaan terhadap keindahan. Sisi batin harus dilatih untuk peka terhadap keindahan. Jika manusia tidak tertarik keindahan alam, bukan berarti alam pada dirinya sendiri tidak indah, tetapi manusia belum tertangkap oleh keindahan alam itu. Alam tetap indah pada dirinya sendiri karena alam memancarkan keindahan abadi.

Balthasar menyakini bahwa Yesus adalah keindahan Allah yang sejati. Lewat Yesus, keindahan memberikan amanat tindakan yang baik dan benar dalam berelasi yang menyangkut hubungan manusia dengan Allah dan ciptaan Allah. Yesus juga adalah cinta Allah kepada manusia. Yesus merupakan jalan, kebenaran, dan hidup. ${ }^{28}$ Memandang Yesus berarti memandang keindahan yang penub cinta. Jika manusia tidak tertarik pada Yesus sebagai keindahan yang penuh cinta, bukan berarti Yesus tidak menarik atau tidak berarti apa-apa, melainkan manusia belum tertangkap Yesus dan belum mengolah kepekaan terhadap keindahan Yesus. Allah keindahan Abadi harus didekati dengan keindahan pula. Oleh karena itu, Keindahan Abadi ini didekati melalui keterbukaan manusia kepada Yesus Kristus, sang Logos, dan meneladani Yesus sebagai keindahan yang penuh cinta. Selain itu, manusia juga harus terbuka oleh Roh Kudus yang membimbing manusia untuk mengarahkan pada kesatuan keindahan Bapa dan Putera. Keindahan ini menjadi keindahan Trinitas yang memancarkan keterkaitan dalam relasi. Persoalannya adalah apa yang menjadi wujud aplikatif keindahan sehingga mampu mengarah pada keindahan Trinitas? Dalam kacamata estetika teologis, diusulkan bahwa sebagai pintu masuk kepada keindahan Abadi itu, cinta manusia kepada ekologi secara estetis.

\section{Cinta Ekologis yang Estetis}

Pendekatan estetika teologis memandang bahwa ekologi ialah keindahan alam yang merupakan percikan keindahan abadi yang menyuarakan baikbiosfer dan benar-antropologis. Keindahan dapat ditangkap ketika manusia memiliki perasaan kagum. Perasaan kagum menarik manusia masuk ke dalam dimensi keindahan, sehingga manusia mengalami cinta terhadap keindahan alam yang menampilkan sebagian keindahan abadi. Perasaan kagum terhadap keindahan tidak bersifat romantis semata. Jika manusia menghargai alam dalam perspektif baik-biosfer, relasinya dengan alam 
menjadi utopis karena alam yang memiliki kehidupan sendiri tidak terkait dengan manusia. Untuk menghindari relasi yang utopis ini, keindahan menuntut paradigma yang realistis yaitu: kekaguman terhadap keindahan alam memicu manusia untuk mengenali alam secara benar-antropologis. Relasi manusia dengan alam berada dalam terang Yang Ilahi bedasarkan relasi cinta. Oleh karena itu, pendekatan estetika teologis mengajak manusia untuk mempunyai cinta ekologis yang estetis.

Cinta ekologis yang estetis merupakan sikap manusia untuk memahami alam yang berbicara. Cinta ekologis yang estetis mengisyaratkan dua pengertian. Pertama yaitu bahwa cinta adalah daya yang membawa kebaikan dan kebenaran dalam semesta. Cinta ini didapatkan dengan cara manusia mengikuti teladan Yesus Kristus. Cinta Yesus Kristus mengarahkan manusia berdamai dengan sesamanya dan dengan alam semesta. Kedua yaitu pengertian estetis yang tidak sekadar keindahan dekoratif, seperti yang ditegaskan sebelumnya oleh Balthasar. Pengertian estetis mengindikasikan kesatuan antara baik dan benar yang mengarahkan pada Yang Ilahi. Yang Estetis Abadi menjadi titik tolak manusia melakukan relasi yang damai dengan sesama manusia dan alam semesta. Relasi manusia dengan alam menandakan penegasan communio ciptaan Allah yang berbeda-beda, yang terwujud dalam aneka hayat di alam semesta. Persekutuan ini mengarah pada persekutuan sejati, yaitu Allah Tritunggal. Persekutuan inilah keindahan penuh cinta.

Cinta ekologis yang estetis menggunakan kekaguman sebagai titik awal berefleksi. Manusia kagum, maka manusia ada. Manusia membutuhkan kekaguman untuk memasuki alam. Manusia tidak pernah mengetahui alam pada dirinya sendiri, maka manusia membutuhkan rasa kagum untuk mengerti alam dengan "baik-biosfer". Kekaguman mengantar manusia untuk bersikap "benar-antropologis". Kekaguman memulai relasi dengan pandangan yang positif, dan membuat relasi terhadap sesuatu menjadi lebih dekat. Tidak ada dikotomi subjek dan objek. Kekaguman ini mengantar pada peleburan antarsubjek dalam kesatuan.

Cinta ekologis estetis berada dalam wilayah batin. Untuk mengolah kemampuan mencintai ekologis estetis, manusia perlu mendengarkan alam secara empatif dan memandang secara generatif. ${ }^{29}$ Pertama, mendengar secara empatif berarti mendengar alam yang berbicara lewat gejala-gejala alam. Penginderaan ini mendorong manusia mengenali alam pada dirinya 
sendiri dan nilai intrinsiknya dikaitkan dengan kehadiran Allah. Kedua, memandang secara generatif. Model ini mendorong batin manusia untuk memandang secara holistik. Di saat manusia memandang alam, serentak manusia melihat keindahan ilahi dan keindahan manusia yang perlu dijaga. Kedua pendekatan ini membantu manusia menjadi seimbang dalam memanfaatkan alam. Jika manusia memanfaatkan alam, manusia harus memperhatikan keseimbangan alam, keseimbangan relasi dengan manusia lain, dan kemuliaan Allah.

Metode mendengarkan empatif dan memandang secara generatif, membutuhkan ilmu pengetahuan. Ilmu pengetahuan menjadi jalan masuk ke wilayah baik-biosfer. Ilmu pengetahuan membantu manusia mengangumi alam semesta dan melihat ketidakteraturan akibat alam yang rusak. Keteraturan merupakan salah satu wujud yang menampilkan keindahan. Manusia yang mengasihi keindahan lewat keteraturan ini, dan berusaha untuk mencari tahu apa yang telah terjadi pada alam. Melalui ilmu pengetahuan, manusia mengidentifikasi alam pada dirinya sendiri dan arah yang ditujunya, sehingga manusia dapat beradaptasi. Agustinus dari Hippo, salah satu dari bapa-bapa Gereja, pernah mengatakan bahwa mengasibi mengandung kerinduan untuk memandang. Mengasihi mendorong seorang untuk mencari pengetahuan tentang yang dikasihinya. ${ }^{30}$ Contoh keteraturan yang merupakan wujud keindahan ialah air. Salah satu sifat air adalah mengalir dari tempat yang tinggi menuju tempat yang rendah dan mengikuti bentuk. Banjir terjadi akibat bentuk ketidakadilan manusia terhadap sifat bawaan air yang mengalir dari hulu menuju hilir. Air membutuhkan keteraturan pada dirinya sendiri agar ia eksis. Manusia perlu melihat keterkaitan antara eksistensinya dengan eksistensi air. Jika tidak terjadi banjir, yang tampak adalah peristiwa keselamatan. Peristiwa keselamatan merupakan keindahan. Peristiwa keselamatan tidak terlepas dari usaha pertobatan ekologis manusia yang bertolak dari Allah, dan dialami setelah manusia mampu menyeimbangkan cara berpikir baikbiosfer dan benar-antropologis.

Cinta ekologis yang estetis mendengungkan persekutuan antara pendekatan benar-antropologis, baik-biosfer, dan estetis-teosentris. Persekutuan ini membawa perbedaan dalam keterkaitan dan kesatuan yang mengacu dan mengarah pada persekutuan Allah Trinitas. Persekutuan Tritunggal merupakan persekutuan yang melukiskan hakikat Allah yang pada dirinya 
sendiri adalah Cinta. Di dalam cinta, ada relasi yang saling memberi dan menerima. Kesatuan ini mengundang segenap ciptaan terlibat dalam persekutuan cinta, yakni persekutuan yang mau mendengar dan memandang penuh cinta terhadap yang terpinggirkan dan yang lemah. Dalam persekutuan ini, cinta ekologis yang estetis tidak berhenti pada metode teologi estetika. Cinta ekologis yang estetis harus menjadi suatu gerakan spiritual, dengan langkah-langkah berikut.

Pertama, ada perubahan dari sistem yang mementingkan ego menuju sistem ekologis dan berpuncak pada sistem teosentris. Saat manusia merasakan jeritan alam yang rusak, serentak manusia mendengarkan jeritan kehidupan manusia lain yang sedang menderita. Jeritan tersebut menandai rusaknya keindahan kesatuan antara keindahan alam, manusia dan Yang Ilahi. Keindahan akan terpancar saat manusia mengendalikan kesenangannya, sehingga tidak muncul degradasi keindahan ilahi. Cinta ekologis yang estetis mencegah manusia tergiur pada keinginan yang primordial.

Kedua, cinta ekologis estetis merupakan panggilan terhadap kekaguman akan keindahan Abadi. Panggilan ini tidak hanya bersifat informatif, melainkan evokatif. Panggilan ini menarik manusia ke wilayah kesadaran yang transformatif. Manusia mengalami pertobatan untuk bersatu dengan Logos. Memandang alam yang terluka, serentak memandang wajah Kristus yang tersalib, karena kesempurnaan Sang Logos dirusak oleh antroposentrisme yang agresif. Eksistensi manusia sebagai citra Allah dirusak oleh keserakahan manusia sendiri. Cinta ekologis estetis bukanlah romantisme dengan alam, tapi panggilan ini lewat kegiatan yang bersentuhan dengan alam dan akhirnya manusia tesergap oleh Yang Ilahi lewat keindahan alam.

Ketiga, cinta ekologis estetis memaknai pengorbanan sebagai persembahan total pada keindahan yang abadi. Pengorbanan makhluk, partikel, organisme dan aneka hayat sekecil apapun yang tidak kasat mata, merupakan persembahan total demi keberlangsungan alam yang berevolusi secara kreatif, agar semakin mendekati kesempurnaan Logos. Pengorbanan ini wujud partisipasi manusia terhadap Kristus Yesus, Sang Logos yang berkorban demi keselamatan manusia. Pengorbanan adalah puncak ketaatan Kristus Yesus kepada Allah Bapa karena dunia yang berdosa ini. Pengorbanan ini menjadi model manusia untuk bertumbuh 
dalam masyarakat, bukan lagi dengan antroposentrisme berlebihan, melainkan karena persekutuan cinta. Pengorbanan dilakukan dengan cara mengendalikan diri (self-denial), selanjutnya mempersembahkan diri (selfsacrifice), demi persekutuan dalam ketaatan. Jika manusiaingin memanfaatkan alam sampai alam mengorbankan dirinya demi manusia, manusia pun harus memberikan pengorbanan dirinya kepada alam. Contohnya, jika manusia menghendaki pemanfaatan ekosistem hutan, manusia pun harus mengorbankan niat, tenaga, dan materi untuk memperbaiki hutan yang telah dimanfaatkan. Pengorbanan dilakukan bertolak dari keindahan Abadi yang perlu dijaga, yang tecermin dalam keindahan alam semesta.

\section{References}

Armstrong, Karen. Compassion: 12 Langkah Menuju Hidup Berbelas Kasih. Penerjemah: Yuliani Liputo. Judul Asli: Twelve Steps to a Compassionate Life. Bandung: Mizan. 2010.

Sejarah Tuhan: Kisah Pencarian Tuhan yang Dilakukan oleb

Orang-Orang Yahudi, Kristen, dan Islam selama 4.000 Tabun. Penerjemah: Zaimul Am dan Yuliani Liputo. Judul Asli: A History Of God: 4.000Year Quest of Judaism, Christianity and Islam. Jakarta: Gramedia. 2010.

Balthasar, Hans Urs von. Love Alone Is Credible. San Fransisco CA.: Ignatius Press. 2004.

The Glory Of The Lord: Theological Aesthetic; Seeing The Form. San Fransisco CA.: Ignatius Press. 1981.

Darwin, Charles. Origin of Species: Teori Evolusi Manusia. Mengenang 200 Tahun Charles Darwin. Jakarta: Gramedia. 2009.

Hadiwardoyo, Purwa. Teologi Ramah Lingkungan. Yogyakarta: Kanisius. 2015.

Hadiwijono, Harun. Sari Sejarah Filsafat Barat 1. Yogyakarta: Kanisius. 1995

Hahn, Scott. First Comes Love: The Family in the Church and the Trinity. London: Darton Longman \& Todd. 2002.

Hamersma, Harry. Tokoh-Tokoh Filsafat Barat Modern. Jakarta: Gramedia. 1983.

Hardiman, Budi. Filsafat Modern. Jakarta: Gramedia. 2004.

Harun, Martin. Ensiklik Laudato Si karya Paus Fransiskus. Jakarta: Obor. 2015. 
Johar, Danar. Ian Marshall. Spiritual Quotient. Bandung: Mizan. 2001.

Krich, Aron, M. Anatomi Cinta. Depok: Komunitas Bambu. 2009.

Kristiyanto, Eddy. Spiritualitas dan Masalah Sosial. Jakarta: Obor. 2005.

Magee, Bryan. The Story Of Philosophy. Yogyakarta: Kanisius. 2008.

Mustika, Wisnu. Saat Alam Semesta Berbicara. Jakarta: Elex Media Komputindo. 2011.

Samosir, Leo. Agama dengan Dua Wajah: Refleksi Teologis atas Tradisi dalam Konteks. Jakarta: Obor. 2010.

Scharmer, Otto. Leading from the Emerging Future: From Ego-System to EcoSystem Economies. San Fransisco: Berrett-Koehler Publishers, Inc. 2013.

Sunarko, Adrianus. Menyapa Bumi Menyembah Hyang Ilabi. Yogyakarta: Kanisius. 2008.

West, Christopher. The Love that Satisfies: Reflections on Eros and Agape. West Chest, Pa.: Ascension Press. 2007.

\section{Endnotes:}

1 Kalimat ini terpajang berwarna hitam, pada sampul depan majalah National Geographic (Edisi 10 tahun National Geographic Indonesia, November, 2015) berwarna kuning. Kalimat tersebut mengekspresikan bahwa tidak ada gambar yang cukup indah untuk menggambarkan perubahan iklim.

2 “Internasional,"Majalab Tempo, Senin, 30 November (2015) 13.

3 Filsafat tradisional mempersoalkan kenyataan adikodrati yang memberikan perhatian kepada tema seperti Allah, Roh, Trasenden dan Ilahi. Semenjak zaman Renaisans, filsuf modern sibuk mempersoalkan cara menemukan dasar pengetahuan yang sah tentang asal mula. Dengan demikian, adanya peralihan minat yang lambat laun, minat refleksi Allah bergeser ke refleksi atas manusia. Dengan kata lain, fokus teosentrisme bergeser ke antroposentrisme; lih. Budi Hardiman, Filsafat Modern (Jakarta: Gramedia, 2004).

4 Lih. John D. Caputo, Agama Cinta Agama Masa Depan (Bandung: Mizan, 2003) 56.

5 Konsep Tuhan berkembang. Dalam sejarah konsep tentang Tuhan, manusia sempat menjadikan alam sebagai Tuhan. Hal tersebut tidak terlepas dari kekuatan alam yang tidak dapat ditandingi oleh manusia. Di berbagai macam tempat, Tuhan disamakan dengan alam lewat ekspresi-ekspresi yang sesuai dengan keadaan geografis. Manusia pada saat itu memunculkan gambaran-gambaran Tuhan lewat dinamisme dan animisme. Lih. Karen Amstrong, History Of God (Jakarta: Gramedia, 2010) 39.

6 Lih. Martin Harun (Penerjemah), Ensiklik Laudato Si karya Paus Fransiskus (Jakarta: Obor, 2015) 85.

7 Lih. Adrianus Sunarko, Menyapa Bumi Menyembab Hyang Ilabi (Yogyakarta: Kanisius, 2008). 
8 Otak tua diwariskan kepada manusia oleh reptil-reptil yang berjuang keluar dari lender primal sekitar 500 juta tahun yang lalu. Dorongan untuk makan, berkelahi, melarikan diri dan kawin, menyebar ke dalam sistem tindakan cepat. Hal in mengingatkan reptil-reptil yang bersaing tanpa ampun untuk mendapat makanan, untuk menangkal ancaman, mendominasi wilayah mereka, mencari teman yang aman dan melestarikan gen mereka. Leluhur reptil hanya tertarik pada status, kekuasaan, kontrol, wilayah, seks, keuntungan pribadi dan kelangsungan hidup. Homo Sapiens telah mewarisi sistem neurologis ini. Lih. Karen Amstrong, Compassion (Bandung: Mizan, 2010) 19.

9 Ketika Charles Darwin menggemparkan dunia melalui kajian ilmiah yaitu teorì evolusi, manusia dilacak awal mulanya berasal dari makhluk kecil lalu menjadi kera, selanjutnya menjadi Homo Sapiens. Lih. Charles Darwin, The Origin Of Species; Mengenang 200 Tabun Charles Darwin (Jakarta: Gramedia, 2009) 88.

10 Seharusnya diperhatikan kembali bahwa kata Ibrani dalam Kitab Kejadian yang diterjemahkan 'memelihara' bermakna literal 'melindungi', sebagaimana para imam Israel menjaga tempat kudus dan melindunginya dari penodaan; lih. Scott Hahn, First Comes Love: Todd, 2002), 16

11 Adrianus Sunarko, Menyapa Bumi Menyembah Hyang Ilabi, op. cit., 159.

12 Martin Harun, Ensiklik. Laudato Si, op. cit., 92.

13 Leo Samosir, Agama dengan Dua Wajab: Refleksi Teologis atas Tradisi dalam Konteks (Jakarta: Obor, 2010) 148.

14 Hans Urs von Balthsar, The Glory of the Lord: A Theological Aesthetics (San Francisco: Ignatius Press, 1983) 79-177.

15 P.H. Embuiru, SVD (Penerjemah), Katekismus Gereja Katolik (Liberia Editrice Vaticana, Citra Del Vaticano, 1993), Propinsi Gerejani Ende (1995) 627, nr. 2500.

16 Pertobatan Ekologis digemakan kembali oleh Paus Fransiskus dalam ensiklik Laudato Si. Sebelum Paus Fransiskus, gema pertobatan ekologi telah ada dalam ensiklikensiklik seperti Pacem In Terris oleh Paus Yohanes XXIII, Redemptor Hominis oleh Paus Yohanes Paulus II, Caritas In Veritatae oleh Paus Benediktus XVI. Keterlibatan Gereja terhadap dunia tidak terlepas dari pemahaman dunia oleh Konsili Vatikan II. Gereja merupakan bagian dari dunia dan mau mengajak dunia untuk kembali ke jalan yang baik, benar dan indah. Masalah ekologis sangat berkaitan dengan masalah sosial yang tidak bisa dilepaskan dari cara manusia berada.

17 Lih. John Stott, Issues Facing Christian Today (London: Marshall Morgan and Scott, 1984).

18 Leo Samosir, Agama dengan Dua Wajah, op. cit., 146.

19 Harry Hamersma, Tokoh-Tokob Filsafat Barat Modern (Jakarta: Gramedia, 1983) 103.

20 Purwa Hadiwardoyo, Teologi Ramah Lingkungan (Yogyakarta: Kanisius, 2015) 99.

21 Danar Johar dan Ian Marshall, Spiritual Quotient (Bandung: Mizan, 2010) 60

22 A posteriori berasal dari 'a' yang berarti dari dan 'posteriori' yang berarti kemudian Bdk. K. Priut, C.M, Drs. J. Adisubroto, dan W.J.S. Poerwadarminta, Kamus LatinIndonesia (Yogyakarta: Kanisius, 1969).

23 Suja `i, Pembuktian Eksistensi Allah atas Dasar Uraian tenteng Penyebab: Pembahasan Jalan kedua dari Lima Jalan Thomas Aquinas (Sinaksak: STFT St. Yohanes, 2004) 25.

24 Dalam pandangan Aristotelian, simbol bukanlah sekadar objek, melainkan sesuatu yang lebih. Simbol merupakan permukaan yang hendak menyingkapkan sesuatu di 
bagian dalam. Dengan kata lain, hakikat esensial dari sesuatu (ousia) tampil dalam simbol tertentu. Lih. Balthasar, The Glory Of The Lord, Theological Aesthetic; Seeing The Form (San Fransisco: Ionatius Pers, 1981) 151.

25 Muhammad Iqbal, Metafisika Persia (Bandung: Mizan, 1990) 93.

26 Wisnu Mustika, Saat Alam Semesta Berbicara (Jakarta: Elex Media Komputindo, 2011) 44.

27 Otto Scharmer, Leading from the Emerging Future: From Ego-System to Eco-System Economies (San Fransisco: Berrett-Koehler Publishers, Inc., 2013) 92

28 Lih. Christopher West, The Love that Satisfies: Reflections on Eros and Agape (West Chest, Pa.: Ascension Press, 2007).

29 Otto Scharmer, Leading from the Emerging Future, op. cit., 45.

30 Eddy Kristiyanto, Spiritualitas dan Masalah Sosial (Jakarta: Obor, 2005) 137. 